\title{
Spectrofluorimetric Determination of Human Serum Albumin Using Terbium-Danofloxacin Probe
}

\author{
Amir M. Ramezani, ${ }^{1}$ Jamshid L. Manzoori, ${ }^{1}$ Mohammad Amjadi, ${ }^{1}$ and Abolghasem Jouyban' \\ ${ }^{1}$ Department of Analytical Chemistry, Faculty of Chemistry, University of Tabriz, Tabriz, Iran \\ ${ }^{2}$ Drug Applied Research Center and Faculty of Pharmacy, Tabriz University of Medical Sciences, Tabriz 51664, Iran
}

Correspondence should be addressed to Jamshid L. Manzoori, manzoori@tabrizu.ac.ir

Received 25 October 2011; Accepted 8 December 2011

Academic Editor: Carmina Montoliu

Copyright (C) 2012 Amir M. Ramezani et al. This is an open access article distributed under the Creative Commons Attribution License, which permits unrestricted use, distribution, and reproduction in any medium, provided the original work is properly cited.

\begin{abstract}
A spectrofluorimetric method is proposed for the determination of human serum albumin (HSA) and bovine serum albumin (BSA) using terbium-danofloxacin $\left(\mathrm{Tb}^{3+}\right.$-Dano) as a fluorescent probe. These proteins remarkably enhance the fluorescence intensity of the $\mathrm{Tb}^{3+}$-Dano complex at $545 \mathrm{~nm}$, and the enhanced fluorescence intensity of $\mathrm{Tb}^{3+}$-Dano is proportional to the concentration of proteins (HSA and BSA). Optimum conditions for the determination of HSA were investigated and found that the maximum response was observed at: $\mathrm{pH}=7.8,\left[\mathrm{~Tb}^{3+}\right]=8.5 \times 10^{-5} \mathrm{~mol} \mathrm{~L}^{-1}$, [Dano $]=1.5 \times 10^{-4} \mathrm{~mol} \mathrm{~L}^{-1}$. The calibration graphs for standard solutions of BSA, HSA, and plasma samples of HSA were linear in the range of $0.2 \times 10^{-6}-1.3 \times 10^{-6} \mathrm{~mol}$ $\mathrm{L}^{-1}, 0.2 \times 10^{-6}-1.4 \times 10^{-6} \mathrm{~mol} \mathrm{~L}{ }^{-1}$, and $0.2 \times 10^{-6}-1 \times 10^{-6} \mathrm{~mol} \mathrm{~L}^{-1}$, respectively. The detection limits $(\mathrm{S} / \mathrm{N}=3)$ for BSA, HSA, and plasma sample of HSA were $8.7 \times 10^{-8} \mathrm{~mol} \mathrm{~L}-1,6.2 \times 10^{-8} \mathrm{~mol} \mathrm{~L}^{-1}$, and $8.1 \times 10^{-8} \mathrm{~mol} \mathrm{~L}^{-1}$, respectively. The applicability of the method was checked using a number of real biological plasma samples and was compared with the UV spectrometric reference method. The results was showed that the method could be regarded as a simple, practical, and sensitive alternative method for determination of albumin in biological samples.
\end{abstract}

\section{Introduction}

The development of novel methods and new techniques for protein determination is very important in a number of areas such as chemical and biochemical analyses, immunodiagnostics, and biotechnology. There is a connection between the content of human serum albumin (HSA) in plasma and some diseases, such as kidney [1] or chronic liver diseases [2] and unstable angina [3] in addition the enhancement of albumin in cerebrospinal fluid (CSF) samples of amyotrophic lateral sclerosis (ALS) patients was reported [4-7]. Application of albumin level in body fluids as a biomarker of these diseases has been suggested, and development of simple and precise methods which could be applicable in routine bioanalytical methods is needed.

According to the above-mentioned facts, determination of HSA is an important issue in clinical diagnosis. Unfortunately, the traditional methods for the determination of proteins have some disadvantages. For example, Lowry [8] assay can be used only for protein concentration $>10 \mathrm{mg} \mathrm{mL}^{-1}$. Bradford [9] assay has the drawback of contaminating vessels. The silver staining method [10] is complicated as multiple steps are involved. So the chemiluminescent analysis [11], fluorimetric analysis, and resonance light scattering [12-14] methods have been proposed due to their high sensitivity and selectivity. Among them, fluorescence method stands out since its obvious sensitivity is some orders of magnitude higher than that of other spectral detections, especially when the method was incorporated into highperformance liquid chromatography (HPLC) and capillary electrophoresis (CE) [15]. It is well known that only proteins possessing phenylalanine, or tryptophan, or a combination there of, exhibit natural fluorescence. But the resulted emission is too weak to be applied for the analysis of proteins (e.g., albumin) at low concentration. In order to solve this problem, protein can be converted into suitable derivatives by chemical derivatization, typically using a derivatization reaction or spectral probes. There are many publications 


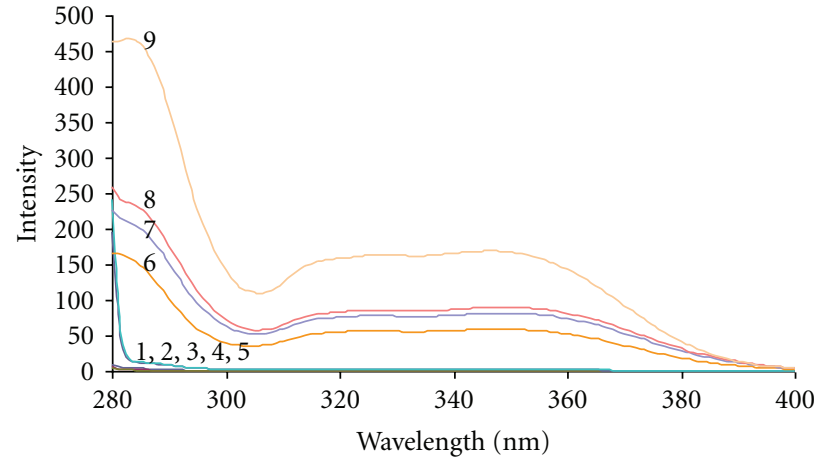

(a) Excition spectra

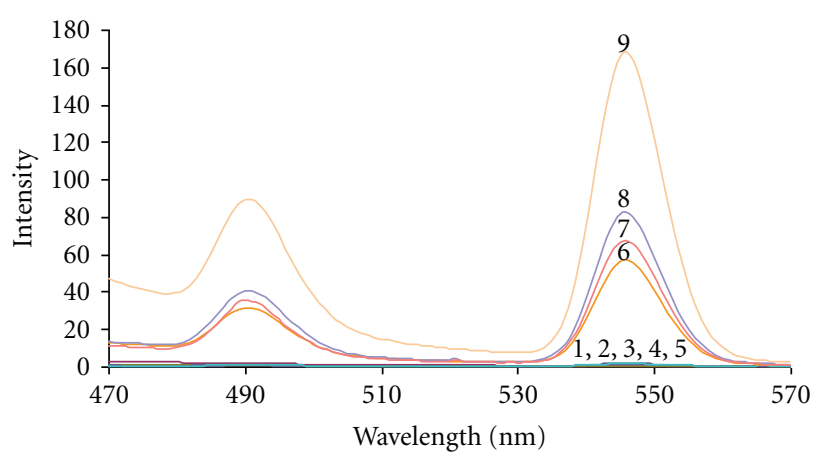

(b) Emission spectra

Figure 1: Excitation and emission spectra. (a): Excitation spectra (b): Emission spectra. (1) $\mathrm{Tb}^{3+}$, (2) BSA, (3) HSA, (4) Tb ${ }^{3+}$-BSA, (5) $\mathrm{Tb}^{3+}$-HSA, (6) $\mathrm{Tb}^{3+}$-Dano, (7) $\mathrm{Tb}^{3+}$-Dano-BSA, (8) $\mathrm{Tb}^{3+}$-Dano-HSA, (9) $\mathrm{Tb}^{3+}$-Dano-HSA (plasma sample). Analytical conditions: [Tb ${ }^{3+}$ ] $=8.5 \times 10^{-5} \mathrm{~mol} \mathrm{~L}^{-1}$, [Dano] $=1.5 \times 10^{-4} \mathrm{~mol} \mathrm{~L}^{-1},[\mathrm{BSA}]=1 \times 10^{-6} \mathrm{~mol} \mathrm{~L}^{-1}$, [HSA] $=1 \times 10^{-6} \mathrm{~mol} \mathrm{~L}^{-1}$, [HSA in plasma sample] $=1 \times$ $10^{-6} \mathrm{~mol} \mathrm{~L}^{-1}, \mathrm{pH}=7.8, \lambda \mathrm{ex} / \lambda \mathrm{em}=347 \mathrm{~nm} / 545 \mathrm{~nm}$.

TABLE 1: Effect of the addition order of reagents on the enhanced fluorescence intensity $(\Delta \mathrm{F} \%)$.

\begin{tabular}{|c|c|c|c|c|}
\hline Reagent & Reagent & Reagent & Reagent & $\Delta \mathrm{F} \%$ \\
\hline $\mathrm{Tb}^{3+}$ & Dano & Albumin & Buffer & 46.6 \\
\hline $\mathrm{Tb}^{3+}$ & Dano & Buffer & Albumin & 37.5 \\
\hline $\mathrm{Tb}^{3+}$ & Buffer & Dano & Albumin & 30.9 \\
\hline $\mathrm{Tb}^{3+}$ & Buffer & Albumin & Dano & 36.9 \\
\hline $\mathrm{Tb}^{3+}$ & Albumin & Dano & Buffer & 34.7 \\
\hline $\mathrm{Tb}^{3+}$ & Albumin & Buffer & Dano & 43.5 \\
\hline Dano & $\mathrm{Tb}^{3+}$ & Albumin & Buffer & 39.5 \\
\hline Dano & $\mathrm{Tb}^{3+}$ & Buffer & Albumin & 41.7 \\
\hline Dano & Buffer & $\mathrm{Tb}^{3+}$ & Albumin & 37.3 \\
\hline Dano & Buffer & Albumin & $\mathrm{Tb}^{3+}$ & 44.2 \\
\hline Dano & Albumin & Buffer & $\mathrm{Tb}^{3+}$ & 43.0 \\
\hline Dano & Albumin & $\mathrm{Tb}^{3+}$ & Buffer & 41.3 \\
\hline Buffer & $\mathrm{Tb}^{3+}$ & Dano & Albumin & 26.5 \\
\hline Buffer & $\mathrm{Tb}^{3+}$ & Albumin & Dano & 24.5 \\
\hline Buffer & Albumin & Dano & $\mathrm{Tb}^{3+}$ & 40.7 \\
\hline Buffer & Albumin & $\mathrm{Tb}^{3+}$ & Dano & 33.6 \\
\hline Buffer & Dano & Albumin & $\mathrm{Tb}^{3+}$ & 41.7 \\
\hline Buffer & Dano & $\mathrm{Tb}^{3+}$ & Albumin & 40.1 \\
\hline Albumin & $\mathrm{Tb}^{3+}$ & Dano & Buffer & 37.6 \\
\hline Albumin & $\mathrm{Tb}^{3+}$ & Buffer & Dano & 40.1 \\
\hline Albumin & Dano & Buffer & $\mathrm{Tb}^{3+}$ & 39.5 \\
\hline Albumin & Dano & $\mathrm{Tb}^{3+}$ & Buffer & 43.1 \\
\hline Albumin & Buffer & $\mathrm{Tb}^{3+}$ & Dano & 31.9 \\
\hline Albumin & Buffer & Dano & $\mathrm{Tb}^{3+}$ & 25.8 \\
\hline
\end{tabular}

Analytical conditions: $\left[\mathrm{Tb}^{3+}\right]: 8.5 \times 10^{-5} \mathrm{~mol} \mathrm{~L}^{-1}$; [Dano]: $1.5 \times 10^{-4} \mathrm{~mol} \mathrm{~L}^{-1} ;[\mathrm{HSA}]: 1 \times 10^{-6} \mathrm{~mol} \mathrm{~L}^{-1} ; \mathrm{pH}=7.8$.

reporting the use of derivatization methods for improving proteins detectability [16-18]. Up to now, a number of fluorescence methods for the determination of proteins have been established based on extrinsic fluorescence probe such as rare earth ions and complexes, or dyes [19-24]. In this work, for the first time, we employ the fluorescence of terbium-danofloxacin $\left(\mathrm{Tb}^{3+}\right.$-Dano) complex as a probe for the determination of albumin. The proposed method was applied to the determination of HSA in human plasma samples and the results were in good agreement with the 


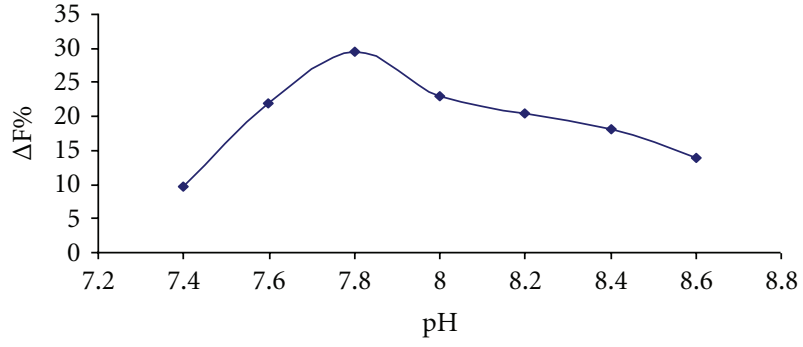

FIGURE 2: Effect of $\mathrm{pH}$ on the enhanced fluorescence intensity $(\Delta \mathrm{F} \%)$ analytical conditions: $\left[\mathrm{Tb}^{3+}\right]: 1 \times 10^{-4} \mathrm{~mol} \mathrm{~L}^{-1}$; [Dano]: 1 $\times 10^{-4} \mathrm{~mol} \mathrm{~L}^{-1}$; [HSA]: $1 \times 10^{-6} \mathrm{~mol} \mathrm{~L}^{-1}$.

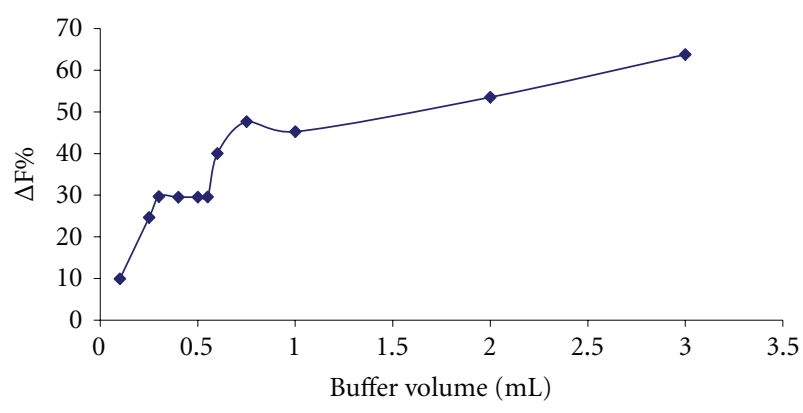

Figure 3: Effect of concentration of Tris buffer on the enhanced fluorescence intensity $(\Delta \mathrm{F} \%)$ analytical conditions: $\left[\mathrm{Tb}^{3+}\right]: 1 \times$ $10^{-4} \mathrm{~mol} \mathrm{~L}^{-1}$; [Dano]: $1 \times 10^{-4} \mathrm{~mol} \mathrm{~L}^{-1}$; [HSA]: $1 \times 10^{-6} \mathrm{~mol} \mathrm{~L}^{-1}$; $\mathrm{pH}=7.8$.

results obtained by the standard UV-Vis spectrophotometer method [25].

\section{Experimental}

2.1. Materials and Methods. Analytical-grade ethanol, hydrochloric acid $(\mathrm{HCl})$, methanol, 2-propanol, acetonitrile, and tris-(hydroxymethyl) aminomethane (Tris) were obtained from Merck (Darmstadt, Germany), terbium(III) chloride hexahydrate $\left(\mathrm{TbCl}_{3} \cdot 6 \mathrm{H}_{2} \mathrm{O}\right)$ from Acros Organics (Geel, Belgium), Dano powder from Jamedat Afagh Pharmaceutical Company (Tehran, Iran), proteins (HSA and BSA) standard solution $\left(1 \times 10^{-4} \mathrm{~g} \mathrm{dL}^{-1}\right)$, and spectrophotometric detection kit from Pars Analysis company (Tehran, Iran). Double-distilled water prepared using the Millipore-Q-plus water purification system (Millipore, Bedford, MA, USA) was used in this study.

A $1.0 \times 10^{-2} \mathrm{~mol} \mathrm{~L}^{-1}$ terbium (III) solution was prepared by dissolving the appropriate amount of $\mathrm{TbCl}_{3} \cdot 6 \mathrm{H}_{2} \mathrm{O}$ in double-distilled water and stored in a polyethylene container to avoid memory effects of terbium adsorbed on glass vessels. A stock solution $\left(1.0 \times 10^{-2} \mathrm{~mol} \mathrm{~L}^{-1}\right)$ of Dano was prepared in double-distilled water, and $0.1 \mathrm{~mol} \mathrm{~L}^{-1}$ Tris-hydrochloric acid (Tris- $\mathrm{HCl}$ ) buffer solution was prepared by dissolving the desired amount of Tris-base in $100 \mathrm{~mL}$ of water, adjusting the $\mathrm{pH}$ to 7.8 with $\mathrm{HCl}$.

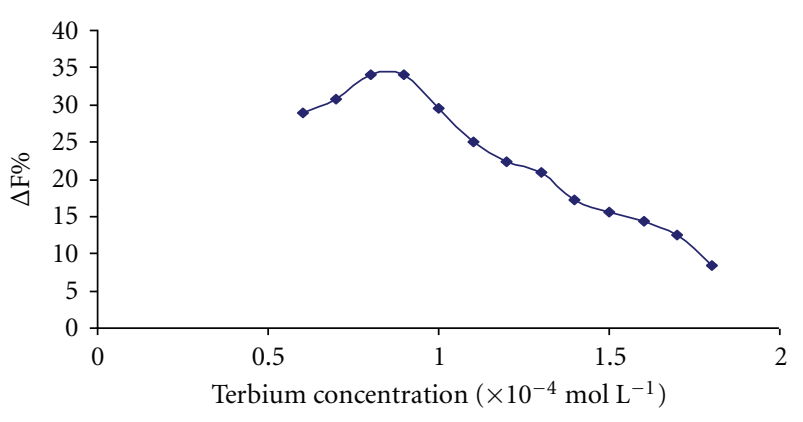

FIgURE 4: Effect of the $\mathrm{Tb}^{3+}$ concentration on the enhanced fluorescence intensity $(\Delta \mathrm{F} \%)$ analytical conditions: [Dano]: $1 \times$ $10^{-4} \mathrm{~mol} \mathrm{~L}^{-1}$; [HSA]: $1 \times 10^{-6} \mathrm{~mol} \mathrm{~L}^{-1} ; \mathrm{pH}=7.8$.

2.2. Apparatus. Fluorescence spectra and intensity measurements were performed on a Jasco FP-750 spectrofluorimeter (Kyoto, Japan) equipped with a $150 \mathrm{~W}$ xenon lamp, using a $10 \mathrm{~mm}$ quartz cell $5 \mathrm{~nm}$. The excitation wavelength was set at $347 \mathrm{~nm}$, and the fluorescence intensity was measured at $545 \mathrm{~nm}$. All measurements were performed at $25^{\circ} \mathrm{C}$, controlled using a Peltier thermostated cell holder (Jasco, Japan). The $\mathrm{pH}$ of solutions was measured with Metrohm $654 \mathrm{pH}$ meter (Herisau, Switzerland).

UV-Vis spectrophotometer (Beckman DU-650, Fullerton) was used for determination of albumin by a detection kit.

\subsection{Sample Preparation}

2.3.1. Standard Sample. The working solutions of HSA and BSA $\left(1 \times 10^{-5} \mathrm{~mol} \mathrm{~L}^{-1}\right)$ were obtained by appropriate dilutions of the standard solutions $\left(1 \times 10^{-4} \mathrm{~g} \mathrm{dL}^{-1}\right)$ with double-distilled water. A $8.5 \times 10^{-4} \mathrm{~mol} \mathrm{~L}^{-1}$ of terbium solution and $1.5 \times 10^{-3} \mathrm{~mol} \mathrm{~L}^{-1}$ of Dano solution were prepared from the stock solutions.

2.3.2. Plasma Sample Preparation. The developed method was applied to the determination and quantification of HSA in plasma samples. As the main proportion of plasma protein content is albumin (about 60\%) [26], the resulted intensities can be regarded due to the albumin content of plasma rather than other rare proteins. For the assay of HSA, the samples must be diluted appropriately within the linear range of the determination of HSA.

\subsection{Experimental Procedure}

2.4.1. Fluorescence Assay. For the analysis of albumin (HSA and BSA) in different samples, solutions were added in the following order: $1 \mathrm{~mL}$ of $8.5 \times 10^{-4} \mathrm{~mol} \mathrm{~L}^{-1} \mathrm{~Tb}^{3+}$ solution, $1 \mathrm{~mL}$ of $1.5 \times 10^{-3} \mathrm{~mol} \mathrm{~L}^{-1}$ Dano solution, suitable aliquots of protein solution, and $0.4 \mathrm{~mL}$ buffer $0.1 \mathrm{~mol} \mathrm{~L}^{-1}(\mathrm{pH}=$ 7.8 ) into $10 \mathrm{~mL}$ calibrated flasks. The mixture was diluted up to $10 \mathrm{~mL}$ with double-distilled water and allowed to stand for $5 \mathrm{~min}$ at room temperature. The fluorescence intensity was measured at $\lambda \mathrm{ex} / \lambda \mathrm{em}=347 \mathrm{~nm} / 545 \mathrm{~nm}$. The enhanced 
TABLE 2: Interference effect on the enhanced fluorescence intensity $(\Delta \mathrm{F} \%)$.

\begin{tabular}{lccc}
\hline Interfere substance & $\left.\begin{array}{c}\text { Concentration of interfere } \\
\text { substance }\left(\times 10^{-3} \text { mol L }\right.\end{array}\right)$ & $\begin{array}{c}\text { Tolerance ratio } \\
\text { (species/HSA })\end{array}$ & Chang of $\Delta \mathrm{I}_{\mathrm{F}} \%$ \\
\hline $\mathrm{Na}^{+}\left(\mathrm{Cl}^{-}\right)$ & 5 & 5000 & 1.3 \\
$\mathrm{Fe}^{3+}\left(\mathrm{Cl}^{-}\right)$ & 0.005 & 5 & -4.2 \\
$\mathrm{~K}^{+}\left(\mathrm{CL}^{-}\right)$ & 3 & 3000 & -2.3 \\
$\mathrm{NH}_{4}^{+}\left(\mathrm{Cl}^{-}\right)$ & 4.2 & 4200 & -4.7 \\
Saccharose & 1 & 1000 & 3.7 \\
$\mathrm{Glycine}^{2+}\left(\mathrm{Cl}^{-}\right)$ & 1 & 1000 & -2.4 \\
$\mathrm{Mn}^{2}$ & 50 & -3.8 \\
$\mathrm{ctDNA}^{3+}\left(\mathrm{Cl}^{-}\right)$ & 0.05 & 0.75 & 3.0 \\
$\mathrm{Ba}^{2+}\left(\mathrm{Cl}^{-}\right)$ & 0.00075 & 5 & -4.9 \\
$\mathrm{Ca}^{2+}\left(\mathrm{Cl}^{-}\right)$ & 0.005 & 1400 & -3.4 \\
$\mathrm{Na}^{+}\left(\mathrm{CO}_{3}^{2-}\right)$ & 1.4 & 1150 & -4.2 \\
\hline $\mathrm{Ant}^{2-}$ & 1.15 & 1900 & -3.7 \\
\hline
\end{tabular}

Analytical conditions: $\left[\mathrm{Tb}^{3+}\right]: 8.5 \times 10^{-5} \mathrm{~mol} \mathrm{~L}^{-1}$; [Dano]: $1.5 \times 10^{-4} \mathrm{~mol} \mathrm{~L}^{-1} ;[\mathrm{HSA}]: 1 \times 10^{-6} \mathrm{~mol} \mathrm{~L}^{-1} ; \mathrm{pH}=7.8$.

TABLE 3: Validation data of the proposed method for quantification of BSA, HSA, and HSA in human plasma.

\begin{tabular}{lccc}
\hline Parameters & BSA & HSA & HSA in plasma \\
\hline Linear range $\left(\mathrm{mol} \mathrm{L}^{-1}\right)$ & $0.2 \times 10^{-6}-1.3 \times 10^{-6}$ & $0.2 \times 10^{-6}-1.4 \times 10^{-6}$ & $0.2 \times 10^{-6}-1 \times 10^{-6}$ \\
Slope & 32.775 & 42.574 & 217.130 \\
Intercept & 3.9446 & 0.2742 & -14.6410 \\
Correlation coefficient & 0.9991 & 0.9990 & 0.9899 \\
Number of data points & 12 & 13 & 9 \\
LOD $\left(\mathrm{mol} \mathrm{L}^{-1}\right)$ & $8.7 \times 10^{-8}$ & $6.2 \times 10^{-8}$ & $8.1 \times 10^{-8}$ \\
\hline
\end{tabular}

fluorescence intensity of $\mathrm{Tb}^{3+}$-Dano by HSA was represented as $\Delta \mathrm{F} \%=100\left(\mathrm{~F}-\mathrm{F}_{0}\right) / \mathrm{F}_{0}$ where $\mathrm{F}$ and $\mathrm{F}_{0}$ are the fluorescence intensities of the systems with HSA and without HSA, respectively.

2.4.2. Standard UV-Vis Spectrophotometry Assay. For the analysis of HSA by standard UV spectrophotometry the following procedure was used: to preparation of blank, standard, and sample solutions, $10 \mu \mathrm{L}$ double-distilled water, $10 \mu \mathrm{L}$ standard solution, and $10 \mu \mathrm{L}$ sample were added into $2 \mathrm{~mL}$ micro tubes containing $1 \mathrm{~mL}$ reagents, respectively.

After complete mixing, the solution should be incubated for $10 \mathrm{~min}$ in $37^{\circ} \mathrm{C}$. The absorbance of the standard and sample solution should be measured against blank solution at $\lambda=546 \mathrm{~nm}$ in $60 \mathrm{~min}$. the concentration is calculated using following formula:

$$
\text { Albumin }\left(\mathrm{mol} \mathrm{L}^{-1}\right)=\frac{\text { Sample Absorbance } \times \text { Standard Concentration }\left(\mathrm{mol} \mathrm{L}^{-1}\right)}{\text { Standard Absorbance }} .
$$

\section{Results and Discussion}

3.1. Fluorescence Spectra. Fluorescence emission and excitation spectra of $\mathrm{Tb}^{3+}$, BSA, HSA, $\mathrm{Tb}^{3+}-\mathrm{BSA}, \mathrm{Tb}^{3+}-\mathrm{HSA} \mathrm{Tb}^{3+}{ }_{-}$ Dano, $\mathrm{Tb}^{3+}$-Dano-BSA, $\mathrm{Tb}^{3+}$-Dano-HSA, and $\mathrm{Tb}^{3+}$-DanoHSA (plasma sample) are shown in Figure $1 . \mathrm{Tb}^{3+}$ solution does not show the characteristic fluorescence spectrum, while by adding Dano to $\mathrm{Tb}^{3+}$ solution, intense fluorescence was observed. The maximal excitation wavelength of $\mathrm{Tb}^{3+}$ Dano occurs at $347 \mathrm{~nm}$ and two emission peaks at 490 and $545 \mathrm{~nm}$, corresponding to the ${ }^{5} \mathrm{D}_{4}{ }^{-}{ }^{7} \mathrm{~F}_{6}$ transition and ${ }^{5} \mathrm{D}_{4}{ }^{-7} \mathrm{~F}_{5}$ transition of $\mathrm{Tb}^{3+}$, respectively. The fluorescence intensity at $545 \mathrm{~nm}$ is the greatest. Therefore, the excitation and emission peaks were set at 347 and $545 \mathrm{~nm}$, respectively. The fluorescence spectrum of the $\mathrm{Tb}^{3+}$-Dano-HSA system was similar to that of $\mathrm{Tb}^{3+}$-Dano; however, the fluorescence intensity of $\mathrm{Tb}^{3+}$-Dano was enhanced by proteins (HSA and BSA), and the complementary experiments showed that the enhancement was proportional to the concentration of the proteins. 
TABLE 4: Intra-assay precision and accuracy of calibration standards.

\begin{tabular}{|c|c|c|c|c|}
\hline Analyte name & $\begin{array}{l}\text { Nominal concentration } \\
\quad\left(\mathrm{mol} \mathrm{L}^{-1}\right)(N=3)\end{array}$ & $\begin{array}{l}\text { Found concentration } \\
\left(\mathrm{mol} \mathrm{L}^{-1}\right)(N=3)\end{array}$ & Precision (RSD\%) & Accuracy (RE \%) \\
\hline \multirow{5}{*}{ BSA } & $0.3 \times 10^{-6}$ & $0.286 \times 10^{-6}$ & 2.78 & -4.5 \\
\hline & $0.5 \times 10^{-6}$ & $0.489 \times 10^{-6}$ & 3.91 & -2.2 \\
\hline & $0.7 \times 10^{-6}$ & $0.714 \times 10^{-6}$ & 3.97 & 1.9 \\
\hline & $1.0 \times 10^{-6}$ & $0.992 \times 10^{-6}$ & 0.50 & -0.8 \\
\hline & $1.2 \times 10^{-6}$ & $1.194 \times 10^{-6}$ & 2.78 & -0.5 \\
\hline \multirow{5}{*}{ HSA } & $0.3 \times 10^{-6}$ & $0.308 \times 10^{-6}$ & 2.85 & 2.9 \\
\hline & $0.5 \times 10^{-6}$ & $0.510 \times 10^{-6}$ & 3.19 & 2.1 \\
\hline & $0.7 \times 10^{-6}$ & $0.713 \times 10^{-6}$ & 3.14 & 1.9 \\
\hline & $1.0 \times 10^{-6}$ & $0.994 \times 10^{-6}$ & 1.53 & -0.5 \\
\hline & $1.2 \times 10^{-6}$ & $1.185 \times 10^{-6}$ & 1.44 & -1.2 \\
\hline \multirow{5}{*}{$\begin{array}{l}\text { HSA in } \\
\text { plasma }\end{array}$} & $0.3 \times 10^{-6}$ & $0.277 \times 10^{-6}$ & 4.13 & -7.6 \\
\hline & $0.5 \times 10^{-6}$ & $0.519 \times 10^{-6}$ & 3.94 & 3.7 \\
\hline & $0.7 \times 10^{-6}$ & $0.711 \times 10^{-6}$ & 5.08 & 1.6 \\
\hline & $0.8 \times 10^{-6}$ & $0.791 \times 10^{-6}$ & 4.23 & -1.0 \\
\hline & $1.0 \times 10^{-6}$ & $0.959 \times 10^{-6}$ & 3.58 & -4.1 \\
\hline
\end{tabular}

TABLE 5: Assay precision and accuracy of quality control samples.

\begin{tabular}{|c|c|c|c|c|}
\hline Analyte name & $\begin{array}{c}\text { Concentration } \\
\left(\mathrm{mol} \mathrm{L}^{-1}\right)\end{array}$ & $\begin{array}{c}\text { Intra-assay precision } \\
(\mathrm{RSD} \%)\end{array}$ & $\begin{array}{c}\text { Inter-assay precision } \\
(\mathrm{RSD} \%)\end{array}$ & Accuracy (RE\%) \\
\hline \multirow{3}{*}{ BSA } & $0.3 \times 10^{-6}$ & 2.62 & 4.55 & -3.9 \\
\hline & $0.7 \times 10^{-6}$ & 4.39 & 1.70 & 1.1 \\
\hline & $1.2 \times 10^{-6}$ & 4.70 & 3.57 & 2.6 \\
\hline \multirow{3}{*}{ HSA } & $0.3 \times 10^{-6}$ & 3.19 & 4.07 & 4.4 \\
\hline & $0.7 \times 10^{-6}$ & 2.79 & 4.62 & 3.1 \\
\hline & $1.2 \times 10^{-6}$ & 2.00 & 2.60 & -0.4 \\
\hline \multirow{3}{*}{$\begin{array}{l}\text { HSA in } \\
\text { plasma }\end{array}$} & $0.3 \times 10^{-6}$ & 6.44 & 8.08 & -6.3 \\
\hline & $0.5 \times 10^{-6}$ & 4.16 & 4.90 & 1.5 \\
\hline & $0.8 \times 10^{-6}$ & 3.85 & 3.58 & -2.7 \\
\hline
\end{tabular}

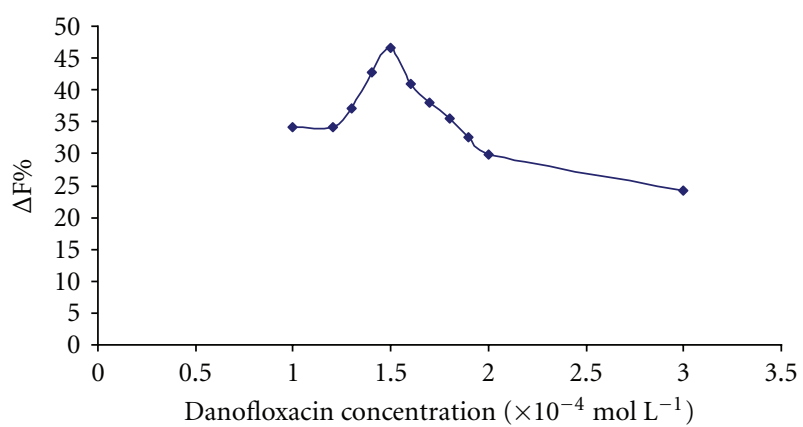

Figure 5: Effect of the amount of Dano on the enhanced fluorescence intensity $(\Delta \mathrm{F} \%)$ analytical conditions: $\left[\mathrm{Tb}^{3+}\right]: 8.5 \times$ $10^{-5} \mathrm{~mol} \mathrm{~L}^{-1}$; [HSA]: $1 \times 10^{-6} \mathrm{~mol} \mathrm{~L}^{-1} ; \mathrm{pH}=7.8$.

\subsection{Optimization of Experimental Conditions}

3.2.1. Effect of $p H$. Fluorescence intensities of series of $0.1 \mathrm{~mol} \mathrm{~L}^{-1}$ Tris- $\mathrm{HCl}$ buffer solutions with the $\mathrm{pH}$ range of 7.4-8.6 were measured at $\lambda \mathrm{ex} / \lambda \mathrm{em}=347 \mathrm{~nm} / 545 \mathrm{~nm}$ (Figure 2). The enhancement intensity $(\Delta \mathrm{F} \%)$ of $\mathrm{Tb}^{3+}$-Dano complex with albumin (HSA and BSA) is strongly dependent on $\mathrm{pH}$ and reaches to maximum value at $\mathrm{pH}$ 7.8. Thus, $\mathrm{pH}$ $7.8\left(0.1 \mathrm{~mol} \mathrm{~L}^{-1}\right.$ Tris buffer) was selected as optimum $\mathrm{pH}$ for the rest of analysis. Below this $\mathrm{pH}$, the hydroxyl groups of Dano are probably in protonated form, which disfavors the complex formation. Also, $\mathrm{Tb}^{3+}$ ion would be precipitated in the strong alkaline medium, which blocked the coordination between the Dano and $\mathrm{Tb}^{3+}$ ion.

3.2.2. Effect of Concentration of Tris Buffer. Tris buffer is known to have chelating properties with lanthanide ions. Hence, it is necessary to optimize its concentration that will afford maximum sensitization of the $\mathrm{Tb}^{3+}$-Dano-HSA system. The influence of Tris buffer concentrations on luminescence intensity of $\mathrm{Tb}^{3+}$ was studied (Figure 3 ) by varying the buffer volume of the buffer in the range of $0.1-3.0 \mathrm{~mL}$ of $0.1 \mathrm{~mol} \mathrm{~L}^{-1}$ buffer solution while the concentrations of $\mathrm{Tb}^{3+}$, Dano, and HSA were $1 \times 10^{-4} \mathrm{~mol} \mathrm{~L}^{-1}$, 
TABLE 6: Absolute and mean recoveries for the studied analytes.

\begin{tabular}{|c|c|c|c|c|c|}
\hline Analyte name & $\begin{array}{l}\text { Nominal concentration } \\
\quad\left(\mathrm{mol} \mathrm{L}^{-1}\right)(N=5)\end{array}$ & $\begin{array}{l}\text { Found concentration } \\
\left(\mathrm{mol} \mathrm{L}^{-1}\right)(N=5)\end{array}$ & Recovery \% & Mean recovery \% & $\begin{array}{c}\text { Precision of recovery } \\
(\mathrm{RE} \%)\end{array}$ \\
\hline \multirow{3}{*}{ BSA } & $0.3 \times 10^{-6}$ & $0.297 \times 10^{-6}$ & 99 & 100.7 & -1.0 \\
\hline & $0.7 \times 10^{-6}$ & $0.698 \times 10^{-6}$ & 99.7 & & -0.3 \\
\hline & $1.2 \times 10^{-6}$ & $1.240 \times 10^{-6}$ & 103.3 & & 3.3 \\
\hline \multirow{3}{*}{ HSA } & $0.3 \times 10^{-6}$ & $0.294 \times 10^{-6}$ & 98 & 99.3 & -2.0 \\
\hline & $0.7 \times 10^{-6}$ & $0.705 \times 10^{-6}$ & 100.7 & & 0.70 \\
\hline & $1.2 \times 10^{-6}$ & $1.190 \times 10^{-6}$ & 99.2 & & -0.8 \\
\hline \multirow{3}{*}{$\begin{array}{l}\text { HSA in } \\
\text { plasma }\end{array}$} & $0.3 \times 10^{-6}$ & $0.283 \times 10^{-6}$ & 94.3 & 95.9 & -5.7 \\
\hline & $0.5 \times 10^{-6}$ & $0.489 \times 10^{-6}$ & 97.8 & & -2.2 \\
\hline & $0.8 \times 10^{-6}$ & $0.765 \times 10^{-6}$ & 95.6 & & -4.4 \\
\hline
\end{tabular}

TABLE 7: Stability at refrigerator $\left(4^{\circ} \mathrm{C}\right)$ for three days.

\begin{tabular}{|c|c|c|c|c|c|c|c|}
\hline \multirow{2}{*}{ Analyte } & \multirow[b]{2}{*}{$\begin{array}{l}\text { Concentration } \\
\left(\mathrm{mol} \mathrm{L}^{-1}\right)\end{array}$} & \multicolumn{2}{|c|}{ After one day at $4^{\circ} \mathrm{C}$} & \multicolumn{2}{|c|}{ After two days at $4^{\circ} \mathrm{C}$} & \multicolumn{2}{|c|}{ After three days at $4^{\circ} \mathrm{C}$} \\
\hline & & $\begin{array}{l}\text { Concentration } \\
\text { found }\left(\mathrm{mol} \mathrm{L}^{-1}\right)\end{array}$ & $\begin{array}{l}\text { Accuracy } \\
(\mathrm{RE} \%)\end{array}$ & $\begin{array}{l}\text { Concentration } \\
\text { found }\left(\mathrm{mol} \mathrm{L}^{-1}\right)\end{array}$ & $\begin{array}{l}\text { Accuracy } \\
(\mathrm{RE} \%)\end{array}$ & $\begin{array}{l}\text { Concentration } \\
\text { found }\left(\mathrm{mol} \mathrm{L}^{-1}\right)\end{array}$ & $\begin{array}{c}\text { Accuracy } \\
(\mathrm{RE} \%)\end{array}$ \\
\hline \multirow{3}{*}{ BSA } & $0.3 \times 10^{-6}$ & $0.224 \times 10^{-6}$ & -25.3 & $0.216 \times 10^{-6}$ & -28.1 & $0.210 \times 10^{-6}$ & -29.9 \\
\hline & $0.7 \times 10^{-6}$ & $0.624 \times 10^{-6}$ & -10.8 & $0.606 \times 10^{-6}$ & -13.4 & $0.589 \times 10^{-6}$ & -15.7 \\
\hline & $1.2 \times 10^{-6}$ & $1.019 \times 10^{-6}$ & -15 & $0.983 \times 10^{-6}$ & -18.1 & $0.962 \times 10^{-6}$ & -19.8 \\
\hline \multirow{3}{*}{ HSA } & $0.3 \times 10^{-6}$ & $0.26 \times 10^{-6}$ & -14.1 & $0.251 \times 10^{-6}$ & -16.1 & $0.249 \times 10^{-6}$ & -16.8 \\
\hline & $0.7 \times 10^{-6}$ & $0.583 \times 10^{-6}$ & -16.6 & $0.569 \times 10^{-6}$ & -18.7 & $0.565 \times 10^{-6}$ & -19.2 \\
\hline & $1.2 \times 10^{-6}$ & $0.995 \times 10^{-6}$ & -17.1 & $0.982 \times 10^{-6}$ & -18.2 & $0.945 \times 10^{-6}$ & -21.2 \\
\hline \multirow{3}{*}{ HSA in plasma } & $0.3 \times 10^{-6}$ & $0.217 \times 10^{-6}$ & -27.5 & $0.216 \times 10^{-6}$ & -27.9 & $0.214 \times 10^{-6}$ & -28.8 \\
\hline & $0.5 \times 10^{-6}$ & $0.430 \times 10^{-6}$ & -13.9 & $0.421 \times 10^{-6}$ & -15.8 & $0.415 \times 10^{-6}$ & -16.9 \\
\hline & $0.8 \times 10^{-6}$ & $0.649 \times 10^{-6}$ & -18.9 & $0.641 \times 10^{-6}$ & -19.8 & $0.637 \times 10^{-6}$ & -20.4 \\
\hline
\end{tabular}

$1 \times 10^{-4} \mathrm{~mol} \mathrm{~L}^{-1}$, and $1 \times 10^{-6} \mathrm{~mol} \mathrm{~L}^{-1}$, respectively. The coordination of $\mathrm{Tb}^{3+}$ ions by Tris prevents the $\mathrm{OH}$ groups of water molecules from surrounding the terbium ions and reduces the complexation of Dano. In lower concentrations of Tris, the buffer could not coordinate terbium ions completely, and the fluorescence intensity is decreased. The results indicated that the fluorescence of the probe in the presence of the analyte at buffer volumes between $0.3 \mathrm{~mL}-$ $0.55 \mathrm{~mL}$ is constant, therefore $0.4 \mathrm{~mL}$ of $0.1 \mathrm{~mol} \mathrm{~L}^{-1}$ Tris buffer was selected as optimum buffer content.

3.2.3. Effect of $\mathrm{Tb}^{3+}$ Concentration. The effect of the $\mathrm{Tb}^{3+}$ concentration on the luminescence intensity enhancement $(\Delta \mathrm{F} \%)$ of $\mathrm{Tb}^{3+}$-Dano-HSA system was studied (Figure 4$)$, at constant concentration of $1 \times 10^{-6} \mathrm{~mol} \mathrm{~L}^{-1} \mathrm{HSA}$. The $\Delta \mathrm{F} \%$ was highest when the concentration of $\mathrm{Tb}^{3+}$ in the mixture was in the rang of $8 \times 10^{-5} \mathrm{~mol} \mathrm{~L}^{-1}-9 \times 10^{-5} \mathrm{~mol} \mathrm{~L}^{-1}$. Intermediate $\mathrm{Tb}^{3+}$ concentration $\left(8.5 \times 10^{-5} \mathrm{~mol} \mathrm{~L}^{-1}\right)$ was chosen for further analysis.

3.2.4. Effect of the Dano Concentration. The influence of the Dano concentration on the fluorescence intensities was studied (Figure 5), and it was found that the fluorescence intensity enhancement of $\mathrm{Tb}^{3+}$-Dano-HSA system reached a maximum when the concentration of Dano was $1.5 \times$
$10^{-4} \mathrm{~mol} \mathrm{~L}^{-1}$. So $1.5 \times 10^{-4} \mathrm{~mol} \mathrm{~L}^{-1}$ was used as optimum concentration of Dano for further study.

3.2.5. Effect of Reaction Time. Under the optimum conditions, the effect of reaction time on the fluorescence intensity was studied. It was found that the fluorescence intensity is stable for about $50 \mathrm{~min}$ after addition of all reagents. This is due to the rapid complex formation between $\mathrm{Tb}^{3+}$ and Dano and HSA. In this study, $5 \mathrm{~min}$ was set as the standard time interval for all fluorescence intensity measurements.

3.2.6. Effect of Temperature. Temperature had significant influence on the fluorescence intensity of the system; at lower temperatures the enhancement fluorescence in the presence of HSA was decreased, therefore we selected room temperature $\left(25^{\circ} \mathrm{C}\right)$ for further study.

3.2.7. Effect of the Addition Order of Reagents. Series of solutions were prepared with different addition orders of reagents but the same concentrations of reagents $(\mathrm{F})$, and their corresponding blank solutions $\left(\mathrm{F}_{0}\right)$ were measured at $\lambda \mathrm{ex} / \lambda \mathrm{em}=347 \mathrm{~nm} / 545 \mathrm{~nm}$. The results showed that different orders of addition of components have significant impact on both $\mathrm{F}$ and $\Delta \mathrm{F} \%$ (Table 1 ). The highest enhancement in the intensity of the fluorescence probe in the presence of albumin 
TABLE 8: Determinations of HSA in different plasma samples obtained from different human blood samples.

\begin{tabular}{|c|c|c|}
\hline \multirow{2}{*}{ Sample number } & The proposed method & Standard UV spectrophotometry \\
\hline & $\begin{array}{c}\text { Found concentration } \\
\left(\times 10^{-4} \mathrm{~mol} \mathrm{~L}^{-1}\right)\left(\mathrm{RSD}^{2}\right)(N=3)\end{array}$ & $\begin{array}{c}\text { Found concentration } \\
\left(\times 10^{-4} \mathrm{~mol} \mathrm{~L}^{-1}\right)(\mathrm{RSD} \%)(N=3)\end{array}$ \\
\hline \multirow{2}{*}{1} & 6.93 & 6.78 \\
\hline & $(4.5)$ & $(1.2)$ \\
\hline \multirow{2}{*}{2} & 6.36 & 6.11 \\
\hline & $(3.4)$ & (2.8) \\
\hline \multirow{2}{*}{3} & 6.46 & 6.20 \\
\hline & $(8.6)$ & (3.9) \\
\hline \multirow{2}{*}{4} & 6.35 & 6.25 \\
\hline & $(4.1)$ & (2.2) \\
\hline \multirow{2}{*}{5} & 6.40 & 6.26 \\
\hline & $(5.2)$ & $(2.4)$ \\
\hline \multirow{2}{*}{6} & 6.09 & 6.01 \\
\hline & $(9.4)$ & $(1.4)$ \\
\hline \multirow{2}{*}{7} & 6.87 & 6.69 \\
\hline & $(8.7)$ & $(2.1)$ \\
\hline
\end{tabular}

was obtained for the addition of reagents in the order of $\mathrm{Tb}^{3+}$, Dano, HSA, and buffer.

3.2.8. Surfactant Effect. In order to improve fluorescence intensity various surfactants such as SDS, SDBS, CTAB, Tween 20, Tween 80, Triton X-100, and Triton X-114 were added to the solution, and their effect was studied. None of the studied surfactants had significant effect on $\Delta \mathrm{F} \%$.

3.2.9. Solvent Effect. The effect of different solvents on fluorescence intensity was investigated at optimum conditions. Although some solvents (e.g., methanol) improved the $\Delta \mathrm{F} \%$, they decreased the fluorescence intensities of the probe in the presence or absence of HSA which can lead to the decreased repeatability. In addition to the decreased repeatability and the nontoxicity of water, it was chosen for further study (Figure 6).

3.3. Interference Studies. The interference of various exogenous substances was tested and shown in Table 2. It was found that except ctDNA, other substances had little effect on the determination of HSA: $1 \times 10^{-6} \mathrm{~mol} \mathrm{~L}^{-1}$ within the acceptable error range $( \pm 5 \%)$.

\subsection{Analytical Applications and Assay Validation}

3.4.1. The Calibration Graphs and Detection Limits. Under the optimum condition defined, the calibration graphs for albumin samples were obtained, and the results are shown in Table 3. It can be seen that there is a linear relationship between the fluorescence intensity of the system and the concentration of analytes in the range of $0.2 \times 10^{-6}-1.3 \times$ $10^{-6} \mathrm{~mol} \mathrm{~L}^{-1}$ for BSA, $0.2 \times 10^{-6}-1.4 \times 10^{-6} \mathrm{~mol} \mathrm{~L}^{-1}$ for HSA standard solutions, $0.2 \times 10^{-6}-1 \times 10^{-6} \mathrm{~mol} \mathrm{~L}^{-1}$ for

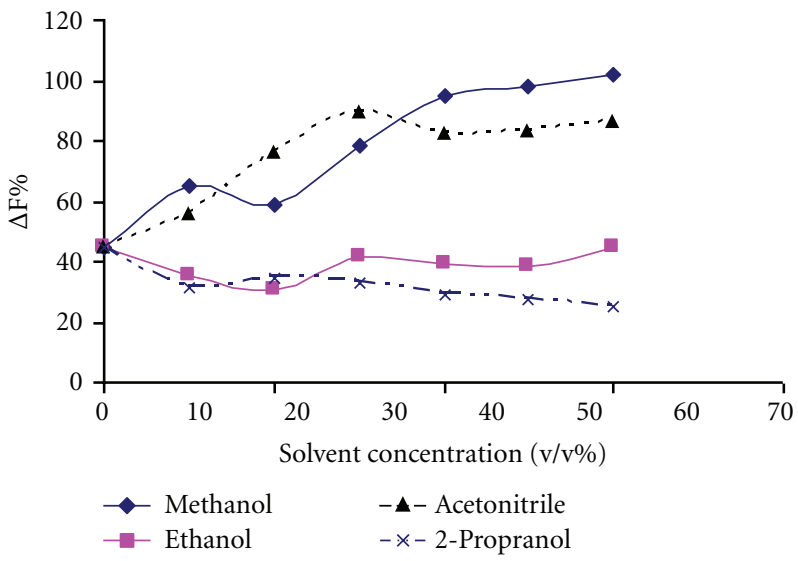

Figure 6: Solvent effect on the enhanced fluorescence intensity $(\Delta \mathrm{F} \%)$ Analytical conditions: $\left[\mathrm{Tb}^{3+}\right]: 8.5 \times 10^{-5} \mathrm{~mol} \mathrm{~L}^{-1}$; [Dano]: $1.5 \times 10^{-4} \mathrm{~mol} \mathrm{~L}^{-1} ;[\mathrm{HSA}]: 1 \times 10^{-6} \mathrm{~mol} \mathrm{~L}^{-1} ; \mathrm{pH}=7.8$.

HSA in plasma samples. The detection limits $(S / N=3)$ for BSA, HSA standard solutions, and plasma samples were 8.7 $\times 10^{-8} \mathrm{~mol} \mathrm{~L}^{-1}, 6.2 \times 10^{-8} \mathrm{~mol} \mathrm{~L}^{-1}$, and $8.1 \times 10^{-8} \mathrm{~mol} \mathrm{~L}^{-1}$, respectively.

3.4.2. Precision and Accuracy. The results of intra-assay precision and accuracy of calibration standards are shown in Table 4. All relative standard deviation (RSD\%) was below 5\% for standard samples and below 15\% for plasma samples which were acceptable for bioanalytical methods according to FDA recommendations [27]. Inter- and intraassay precisions along with accuracy for quality control samples are listed in Table 5. Similar results obtained for these validation experiments showed that the developed method is both accurate and precise. 
3.4.3. Recovery. The recoveries for the investigated albumin samples are summarized in Table 6. The mean recoveries for BSA, HSA, and HSA in plasma were $100.7 \%$, 99.3\%, and 95.9\%, respectively.

3.4.4. Stability. Under the optimum conditions proposed stability of the probe was investigated. It was found that the fluorescence intensity is stable for about $50 \mathrm{~min}$ at room temperature $\left(25^{\circ} \mathrm{C}\right)$ after addition of all reagents. Stability at refrigerator temperature $\left(4^{\circ} \mathrm{C}\right)$ for three days after addition of all reagents was investigated. After one day decrease in the concentration of analyte is highest but in the second and third days the deviation is less than the first day. The stability results at refrigerator temperature $\left(4^{\circ} \mathrm{C}\right)$ are summarized in Table 7.

3.4.5. Analysis of Plasma Samples. The calibration curve in plasma was used for the determination of HSA in the human plasma and compared with the UV spectrophotometric method. The results are shown in Table 8. This method of measuring protein is more sensitive compared with the routine method.

\section{Conclusions}

In this paper, a new fluorimetric method for the determination of albumin is reported. Under optimum conditions, the enhanced intensity of fluorescence is in proportion to the concentration of albumin. Compared with standard spectrophotometric method, the developed method has the advantages of the simplicity and fast processing, low detection limits and wide linear range. So the proposed method is applicable to the determination of albumin in plasma samples in decreased or enhanced levels. The developed method is applicable in bioanalytical laboratories as routine albumin analysis method.

\section{Acknowledgments}

The authors thank the Iranian Blood Transfusion Research Center (Tabriz, Iran) for donating drug-free plasma samples, and so, they would like to thank Dr. Somaieh Soltani and Dr. Ali Shayanfar for their help in this study.

\section{References}

[1] A. N. Friedman and S. Z. Fadem, "Reassessment of albumin as a nutritional marker in kidney disease," Journal of the American Society of Nephrology, vol. 21, no. 2, pp. 223-230, 2010.

[2] F. Wong, "Drug insight: the role of albumin in the management of chronic liver disease," Nature Clinical Practice Gastroenterology \& Hepatology, vol. 4, pp. 43-51, 2007.

[3] S. Ju, J. Ni, J. Su, M. Pan, and J. Zhu, "Ischemia-modified albumin is increased in patients with unstable angina: a new potential diagnostic biomarker of this acute coronary syndrome?" Laboratory Medicine, vol. 39, no. 11, pp. 668-670, 2008.

[4] P. Annunziata and N. Volpi, "High levels of C3c in the cerebrospinal fluid from amyotrophic lateral sclerosis patients," Acta Neurologica Scandinavica, vol. 72, no. 1, pp. 61-64, 1985.
[5] S. Apostolski, J. Nikolic, C. Bugarski-Prokopljevic, V. Miletic, S. Pavlovic, and S. Filipovic, "Serum and CSF immunological findings in ALS," Acta Neurologica Scandinavica, vol. 83, no. 2, pp. 96-98, 1991.

[6] A. Leonardi, G. Abbruzzese, and L. Arata, "Cerebrospinal fluid (CSF) findings in amyotrophic lateral sclerosis," Journal of Neurology, vol. 231, no. 2, pp. 75-78, 1984.

[7] G. Meucci, G. Rossi, R. Bettini et al., "Laser nephelometric evaluation of albumin, IgG and $\alpha 2$-macroglobulin: applications to the study of alterations of the blood-brain barrier," Journal of the Neurological Sciences, vol. 118, no. 1, pp. 73-78, 1993.

[8] O. H. Lowry, N. J. Rosebrough, A. L. Farr, and R. J. Randall, "Protein measurement with the Folin phenol reagent," The Journal of Biological Chemistry, vol. 193, pp. 265-275, 1951.

[9] M. M. Bradford, "A rapid and sensitive method for the quantitation of microgram quantities of protein utilizing the principle of protein dye binding," Analytical Biochemistry, vol. 72, no. 1-2, pp. 248-254, 1976.

[10] K. Ohsawa and N. Ebata, "Silver stain for detecting 10femtogram quantities of protein after polyacrylamide gel electrophoresis," Analytical Biochemistry, vol. 135, no. 2, pp. 409-415, 1983.

[11] T. Hara, K. Tsukagoshi, and T. Yoshida, "Determination of a small amount of biological constituent by use of chemiluminescence. XIII. High sensitive metal chelate affinity chromatography," Bulletin of the Chemical Society of Japan, vol. 61, pp. 2779-2783, 1988.

[12] C. Z. Huang, Y. F. Li, and P. Feng, "Determination of proteins with $\alpha, \beta, \gamma, \delta$-tetrakis(4-sulfophenyl)porphine by measuring the enhanced resonance light scattering at the air/liquid interface," Analytica Chimica Acta, vol. 443, no. 1, pp. 73-80, 2001.

[13] Y. J. Chen, J. H. Yang, X. Wu, T. Wu, and Y. X. Luan, "Resonance light scattering technique for the determination of proteins with resorcinol yellow and OP," Talanta, vol. 58, no. 5, pp. 869-874, 2002.

[14] R. P. Jia, L. J. Dong, Q. F. Li, X. G. Chen, and Z. D. Hu, "A highly sensitive assay for protein with dibromochloro-arsenazo- $\mathrm{Al}^{3+}$ using resonance light scattering technique and its application," Talanta, vol. 57, no. 4, pp. 693-700, 2002.

[15] P. R. Banks, "Fluorescent derivatization for low concentration protein analysis by capillary electrophoresis," Trends in Analytical Chemistry, vol. 17, no. 10, pp. 612-622, 1998.

[16] I. Benito, M. L. Marina, J. M. Saz, and J. C. Diez-Masa, "Detection of bovine whey proteins by on-column derivatization capillary electrophoresis with laser-induced fluorescence monitoring," Journal of Chromatography A, vol. 841, no. 1, pp. 105-114, 1999.

[17] G. D. Li, I. S. Krull, and S. A. Cohen, "Electrochemical activity of 6-aminoquinolyl urea derivatives of amino acids and peptides. Application to high-performance liquid chromatography with electrochemical detection," Journal of Chromatography A, vol. 724, no. 1-2, pp. 147-157, 1996.

[18] P. Fadden and T. A. J. Haystead, "Quantitative and selective fluorophore labeling of phosphoserine on peptides and proteins: characterization at the attomole level by capillary electrophoresis and laser-induced fluorescence," Analytical Biochemistry, vol. 225, no. 1, pp. 81-88, 1995.

[19] N. Li, K. A. Li, and S. Y. Tong, "Fluorometric determination for micro amounts of albumin and globulin fractions without separation by using $\alpha, \beta, \gamma, \delta$-tetra( $4^{\prime}$-carboxyphenyl)porphin," Analytical Biochemistry, vol. 233, no. 2, pp. 151-155, 1996. 
[20] S. H. Lee, J. K. Suh, and M. Li, "Determination of bovine serum albumin by its enhancement effect of Nile Blue fluorescence," Bulletin of the Korean Chemical Society, vol. 24, no. 1, pp. 45-48, 2003.

[21] Z. Jia, J. Yang, X. Wu, F. Wang, C. Guo, and S. Liu, "Fluorometric determination of proteins using the terbium (III)-2thenoyltrifluoroacetone-sodium dodecyl benzene sulfonateprotein system," Journal of Luminescence, vol. 121, no. 2, pp. 535-543, 2006.

[22] X. Wu, J. Zheng, C. Guo et al., "Determination of albumins by its quenching effect on the fluorescence of $\mathrm{Tb}^{3+}$-oxolinic acid complex in presence of sodium dodecyl sulphate," Journal of Luminescence, vol. 126, no. 1, pp. 171-176, 2007.

[23] Y. Guo, J. Yang, X. Wu, and H. Mao, "Sensitive determination of protein based on the fluorescence enhancement effect of terbium (iii)-epinephrine-protein-sodium dodecylsulfate system," Luminescence, vol. 24, no. 6, pp. 372-378, 2009.

[24] X. Wang, X. Wang, Y. Wang, and Z. Guo, “Terbium(III) complex as a luminescent sensor for human serum albumin in aqueous solution," Chemical Communications, vol. 47, pp. 8127-8129, 2011.

[25] B. T. Doumas, W. Ard Watson, and H. G. Biggs, "Albumin standards and the measurement of serum albumin with bromcresol green," Clinica Chimica Acta, vol. 31, no. 1, pp. 8796, 1971.

[26] L. Thadikkaran, M. A. Siegenthaler, D. Crettaz, P. A. Queloz, P. Schneider, and J. D. Tissot, "Recent advances in blood-related proteomics," Proteomics, vol. 5, no. 12, pp. 3019-3034, 2005.

[27] S. Bansal and A. DeStefano, "Key elements of bioanalytical method validation for small molecules," AAPS Journal, vol. 9, no. 1, article 11, 2007. 


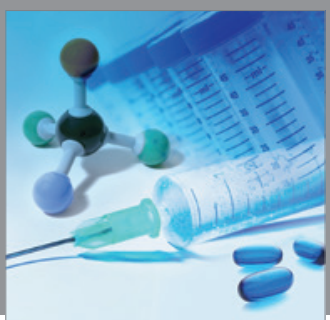

International Journal of

Medicinal Chemistry

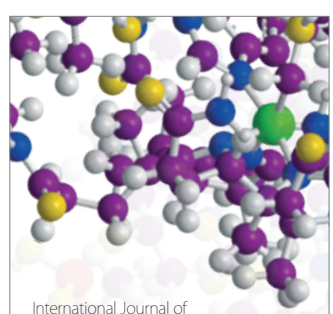

Carbohydrate Chemistry

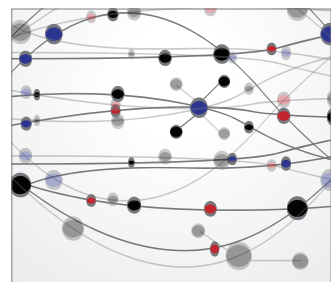

The Scientific World Journal
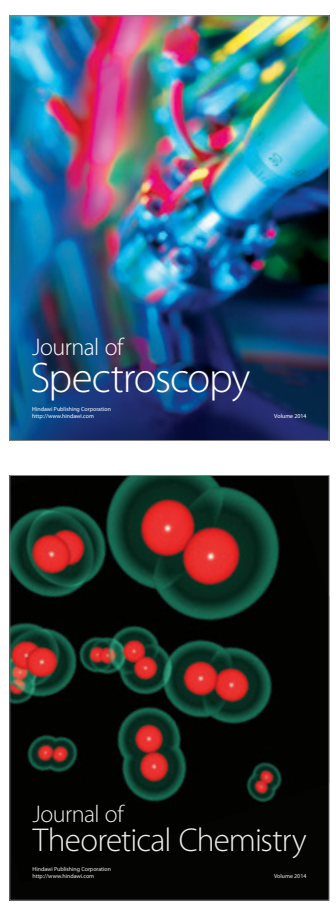
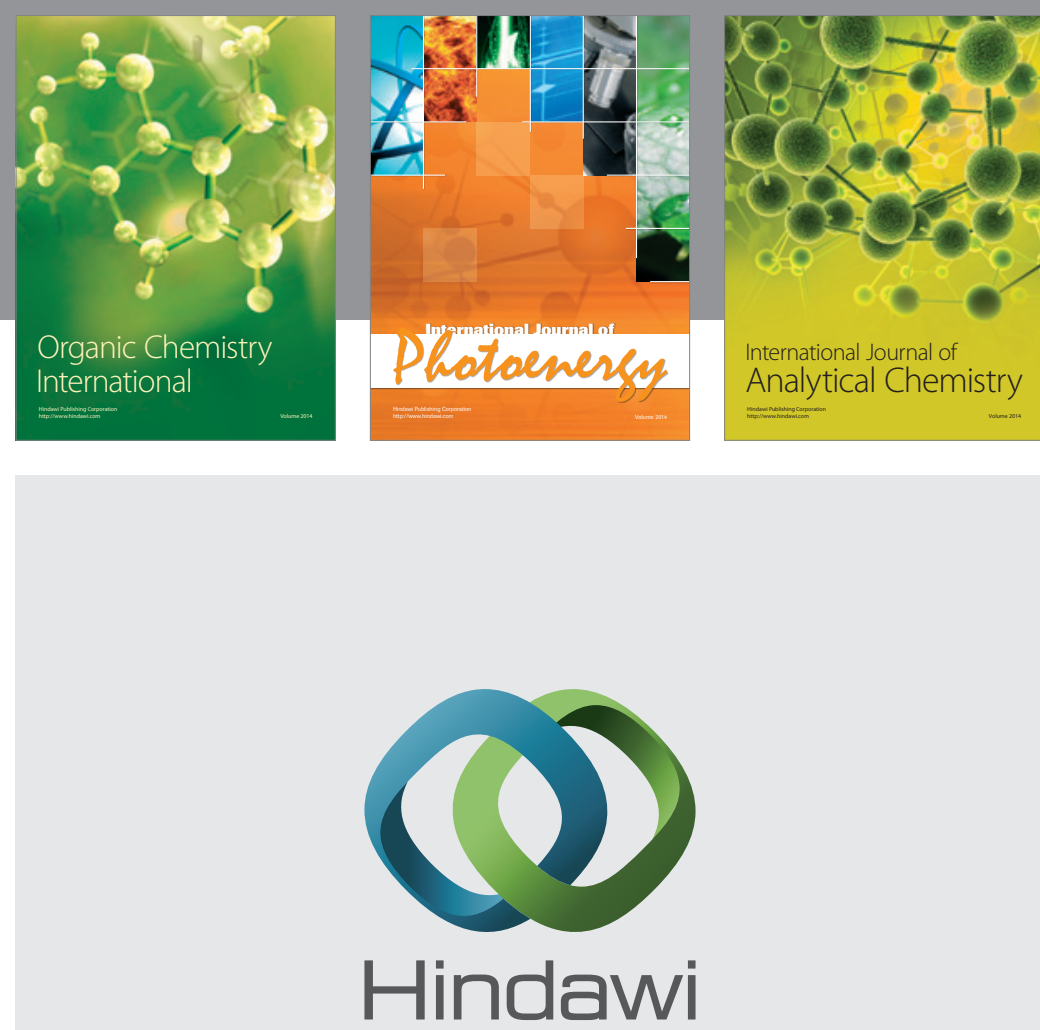

Submit your manuscripts at

http://www.hindawi.com
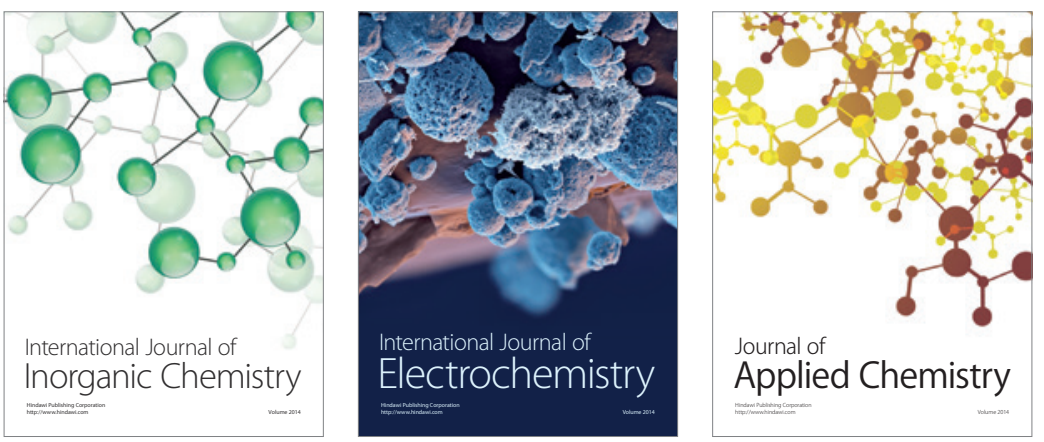

Journal of

Applied Chemistry
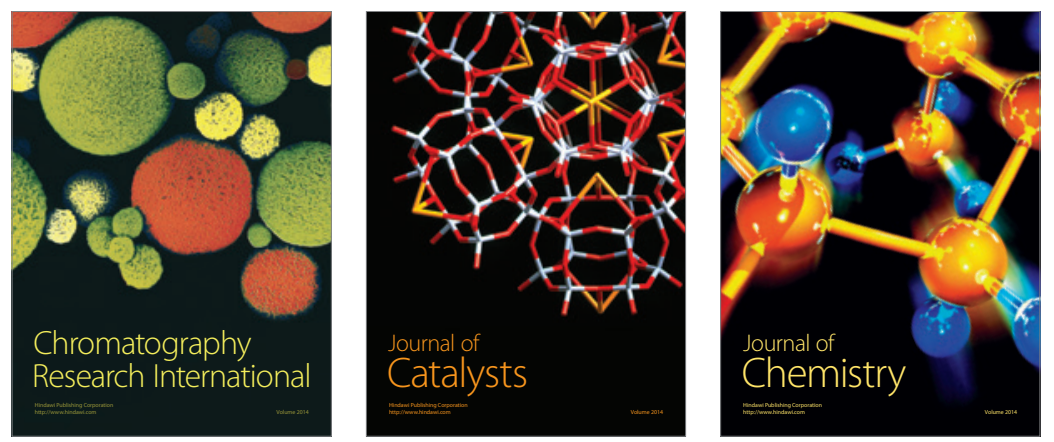
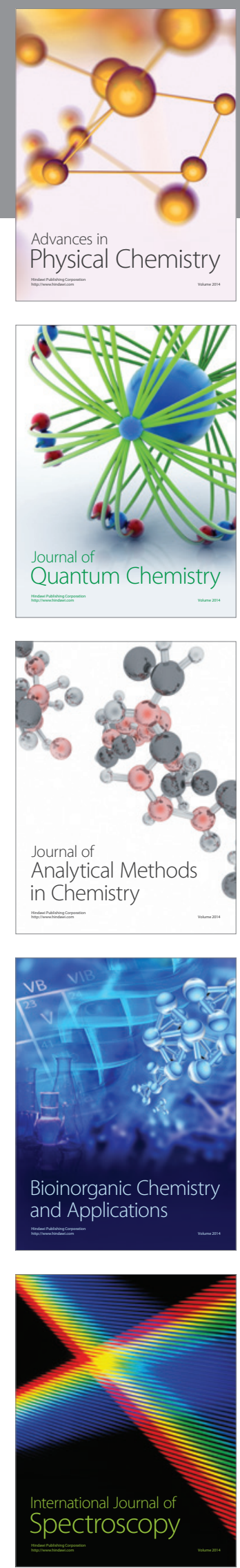